\title{
Comparison of continuous use of thoracic epidural analgesia and intercostal block for pain management after thoracotomy
}

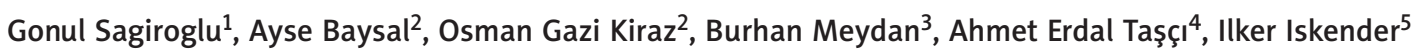 \\ ${ }^{1}$ Department of Anesthesiology and Reanimation, Faculty of Medicine, Trakya University, Edirne, Turkey \\ ${ }^{2}$ Department of Anesthesiology and Reanimation, Kartal Kosuyolu Research and Training Hospital, Kartal, Istanbul, Turkey \\ ${ }^{3}$ Department of Anesthesiology and Reanimation Sureyyapasa Chest Disease and Thoracic Surgery Hospital, Basibuyuk, \\ Istanbul, Turkey \\ ${ }^{4}$ Department of Thoracic Surgery Kartal Kosuyolu Research and Training Hospital, Kartal, Istanbul, Turkey \\ ${ }^{5}$ Department of Thoracic Surgery, Sureyyapasa Chest Disease and Thoracic Surgery Hospital, Basibuyuk, Istanbul, Turkey
}

Kardiochirurgia i Torakochirurgia Polska 2013; 10 (3): 244-250

\begin{abstract}
Aim of the study: We aimed to compare the efficacy of the continuous use of thoracic epidural and intercostal analgesia for post-thoracotomy pain.

Material and methods: Sixty patients completed a prospective, randomized, double-blinded study. The patients were randomized to receive thoracic epidural (group $1, n=30$ ) or intercostal block (group 2, $n=30$ ) for 24 hours. In both groups, $0.25 \%$ bupivacaine was infused at a rate of $5 \mathrm{ml} / \mathrm{h}$ through an inserted catheter. Visual analog scale at rest (VAS-R) and after coughing (VAS-C) scores were recorded at baseline and at 1, 6 and 24 hours after surgery to evaluate pain. Morphine consumption, complications and side effects were recorded as well.

Results: VAS-R and VAS-C scores were similar at baseline; however, $1^{\text {st }}, 6^{\text {th }}$ and $24^{\text {th }}$ hour scores of group 1 were significantly lower than the scores of group 2 (for VAS-R; $p=0.017$, $p=0.001, p=0.023$, for VAS-C; $p=0.006, p=0.002, p=0.032$, respectively). 24-hour morphine consumption was lower in group 1 in comparison to group $2(p=0.032)$. In group 1 , 5 out of 30 patients (17\%) experienced hypotension, compared with none in group $2(p=0.02)$.

Conclusions: For post-thoracotomy pain, better control of analgesia is observed with the thoracic epidural technique; however, intercostal block constitutes an alternative method as it is characterized by lower incidence of hypotension.

Key words: pain, thoracotomy, thoracic epidural block, intercostal nerve block.
\end{abstract}

\section{Streszczenie}

Cel pracy: Celem pracy było porównanie skuteczności ciągłego stosowania znieczulenia zewnątrzoponowego piersiowego oraz blokady międzyżebrowej do leczenia bólu po torakotomii. Materiał i metody: Sześćdziesięciu chorych ukończyło prospektywne badanie z randomizacją przeprowadzone metodą podwójnie ślepej próby. Pacjentów losowo przydzielono do grupy otrzymującej piersiowe znieczulenie zewnątrzoponowe (grupa 1., $n=30$ ) lub blokadę międzyżebrową (grupa 2., $n=30$ ) przez 24 godziny. W obu grupach podawano bupiwakainę o stężeniu 0,25\% w ilości 5 ml/godzinę przy użyciu cewnika. W celu oceny bólu użyto wizualnej skali analogowej w spoczynku (VAS-R) i po kaszlu (VAS-C). Wyniki pobrano na początku badania, jak również 1, 6 i 24 godziny po zabiegu. Zebrano także dane dotyczące zużycia morfiny, powikłań i efektów niepożądanych.

Wyniki: Wartości VAS-R i VAS-C na początku były podobne, jednak wyniki uzyskane po upływie 1, 6 i 24 godzin były znacząco niższe w grupie 1. niż w grupie 2. (odpowiednio $p=0,017$, $p=0,001, p=0,023$ dla VAS-R oraz $p=0,006, p=0,002, p=0,032$ dla VAS-C). Zużycie morfiny na 24 godziny $w$ grupie 1 . było niższe w porównaniu z grupą 2. ( $p=0,032)$. W grupie 1 u 5 z 30 pacjentów (17\%) wystąpiło niedociśnienie, w grupie 2. nie zanotowano takich przypadków $(p=0,02)$.

Wniosek: W przypadku bólu po torakotomii lepszą kontrolę analgezji uzyskuje się za pomocą znieczulenia zewnątrzoponowego piersiowego, jednak blokada międzyżebrowa stanowi alternatywę, ponieważ jest związana z mniejszą częstością występowania niedociśnienia.

Słowa kluczowe: ból, torakotomia, znieczulenie zewnątrzoponowe piersiowe, blokada nerwu międzyżebrowego.

Address for correspondence: Dr. Ayse Baysal, Kartal Kosuyolu Research and Training Hospital, Department of Anesthesiology and Reanimation, Denizer Cad. No. 3 Kartal 34400, Istanbul, Turkey; tel. 902164562436, e-mail: draysebay@yahoo.com 


\section{Introduction}

Inadequate treatment of pain has negative effects on patients' recovery. Thoracotomy has been known as one of the most painful procedures [1]. Post-thoracotomy pain is associated with the deterioration of pulmonary functions of the patient. Thoracotomy may cause trauma to the rib cage; factors that may cause this pain include distortion of the rib cage, retraction of the ribs, disconnection of the adhesive fibrous connections of the rib cage, and damage of the chest wall muscles [2]. The pain may cause complications, such as decreased respiratory movements, inability to remove bronchial secretions resulting from diminished coughing, atelectasis, pneumonia, bronchitis, hypoxemia, respiratory failure, and prolonged mechanical ventilation [2-4].

Epidural block, intercostal block, and paravertebral block are the most commonly used methods of regional anesthesia for managing pain after thoracotomy [3-6]. However, it is still unclear which method is the most effective. Morbidly obese patients or patients with previous history of spinal surgery may not be good candidates for the placement of an epidural catheter due to anatomical changes [7].

Continuous infusion of a local anesthetic into an incision may help reduce the amount of narcotics required to control postoperative pain. Intercostal block is a simple and effective method of analgesia after upper abdominal or thoracic surgery. The use of intermittent bolus doses of local anesthetics or continuous infusions of local anesthetics through an intercostal catheter have been reported to relieve post-thoracotomy pain $[3,4,8,9]$. The average duration of analgesia after an intercostal block with $0.25 \%$ bupivacaine has been shown to vary between 3 and 18 hours $[4,9]$. As this method avoids injections, it is a preferable technique for adequate pain control. In general, both epidural and intercostal block techniques pose difficulties in the placement of a catheter into the correct position to provide adequate pain relief; therefore, neither technique is considered to be superior [10-13]. Although the use of parenteral opioids after operations appeared to be safe, opioids have been shown to cause pain, respiratory depression, nausea, and intestinal dysfunction after thoracotomy procedures [11, 14].

There are several studies on the use of intercostal blocks during thoracotomy pain management; however, only a few large randomized, controlled studies have been conducted comparing the effects of continuous use of thoracic epidural and intercostal block on pain management [8-13].

In a prospective, randomized, double-blinded study, we compared the quality of analgesia and the incidence of adverse events during the continuous use of thoracic epidural and intercostal catheters.

\section{Material and methods}

After institutional review board approval, and written informed consent, seventy-three adult patients aged 19-86 with ASA (American Society of Anesthesiologists) classes of 1,2 , and 3 were enrolled in a prospective, randomized study concerning pain management after posterolateral thoracotomy.

Randomization into two groups was performed using sealed envelopes. The patients were assigned to groups with the use of numbers concealed in envelopes, which were opened before the induction of anesthesia by healthcare personnel. The observers who collected the visual analogue scale (VAS) scores and other data were blinded to the pain relief protocol. The information concerning the method and medication used for pain relief was not provided to the observers. Nurses and doctors were not blinded, but they did not participate in the collection and interpretation of the data.

From the total of 73 patients who fulfilled the inclusion criteria and were included in the study, eight patients were unable to complete the study due to problems related to catheter insertion or the discontinuance of local anesthetic infusion after dislocation of the catheter from its place; in five patients, extubation was delayed, as they did not meet the criteria for extubation after surgery, resulting in their transfer to the intensive care unit on mechanical ventilation. The extubation criteria included: hemodynamic stability, pulse oximetry values above $95 \%$ showing normoxemia, patient temperature between $35^{\circ} \mathrm{C}$ and $37^{\circ} \mathrm{C}$, sufficient tidal volume of 5 to $8 \mathrm{ml} / \mathrm{kg}$, respiratory rate of less than 20 breaths/min, adequate minute ventilation, and positive gag reflexes.

The exclusion criteria of the study included: contraindications for epidural catheter placement (puncture of the skin, infection, bacteremia, hypovolemia, platelet count $<100,000 / \mathrm{mm}^{3}$, prolonged coagulation tests, vertebral column deformity), preoperative pulmonary dysfunction [forced vital capacity (FVC) $<60 \%$ or the first second forced expiratory volume $\left(\mathrm{FEV}_{1}\right)<60 \%$ ], chronic pain resulting from the constant use of analgesic drugs, liver or kidney failure, alcohol or drug abuse, and a history of allergy to local anesthetics.

The patients were randomized to receive either thoracic epidural (group 1, $n=30$ ) or intercostal blocks (group 2, $n=30$ ) for 24 hours. In both groups, $0.25 \%$ bupivacaine solution was prepared by diluting $0.5 \%$ bupivacaine (Bustesin $0.5 \%$, Vem Pharmaceutical, Turkey) in $0.9 \%$ sodium chloride solution in a 1:1 ratio. The infusion through the inserted catheter was started at the rate of $5 \mathrm{ml} / \mathrm{h}$ for 24 hours in total.

On arrival at the operating room and before general anesthesia, the patients in the thoracic epidural group received thoracic epidural catheters (Epidural Minipack, Portex, Turkey) after sterile preparation of the thoracic region. Each catheter was placed in the thoracic epidural space at the $T_{5}-T_{7}$ level using a 16-gauge Tuohy needle (Epidural Minipack, Portex, Turkey) with the loss of resistance technique, while the patients were in a sitting position. The catheter was advanced 4 to $5 \mathrm{~cm}$ into the epidural space and a test dose of $3 \mathrm{ml}$ of $2 \%$ lidocaine (Jetmonal $2 \%$, Adeka Pharmaceutical, Turkey) with epinephrine $5 \mu \mathrm{g} / \mathrm{ml}$ was administered to exclude misplacement of the catheter. 
All surgical procedures were performed by the same surgical team through posterolateral thoracotomy incisions in the $5^{\text {th }}$ or $6^{\text {th }}$ intercostal space.

At the end of the operation, before the chest was closed, the parietal pleura at the $T_{5}-T_{7}$ intercostal space was raised medially as far as the vertebral bodies. A percutaneous epidural catheter (Epidural Minipack, Portex, Turkey) was inserted through a 16-gauge disposable Tuohy needle. A small opening was made in the extrapleural fascia using Lahey's forceps and the tip of the cannula was passed directly into the intercostal space. The catheter was secured with a 4-0 prolene suture to maintain its position during lung expansion.

On the patient's arrival at the intensive care unit, an intercostal blockade of the two spaces above and below the thoracotomy incision was performed using $2 \mathrm{ml}$ of $0.5 \%$ bupivacaine in each intercostal space. Infusions through either epidural or intercostal catheters placed in the thoracotomy incisions were started using infusion pumps (Lifecare 5000, Abbott Laboratories Ltd, Istanbul, Turkey). Bolus injections were not administered in either group of patients; however, $0.25 \%$ bupivacaine was infused at the rate of $5 \mathrm{ml} / \mathrm{h}$ through the inserted catheter in the postoperative care unit after obtaining a baseline 0-hour VAS score. The catheters were removed on the second day after the operation.

Demographic data, age, height, weight, body mass in$\operatorname{dex}(\mathrm{BMI})$, pulmonary function parameters, comorbid diseases, cancer, and histological type were recorded. Preoperative pulmonary function was evaluated with the $\mathrm{FEV}_{1}$ and FVC parameters. $\mathrm{FEV}_{1}$ (\% predicted) and FVC (\% predicted) values were also determined. In addition, arterial blood gas $\mathrm{PaO}_{2}$ (arterial partial pressure of oxygen), $\mathrm{PCO}_{2}$ (arterial partial pressure of carbon dioxide), and $\mathrm{SaO}_{2}$ (arterial oxygen saturation) values were recorded preoperatively as well as 1, 6, and 24 hours after the procedure.

In addition to the standard monitoring used during general anesthesia, which includes two-lead ECG (leads II and V5) for heart rate and ST segment changes, non-invasive pulse oximetry $\left(\mathrm{SpO}_{2}\right)$, oesophageal temperature, and endtidal carbon dioxide $\left(\mathrm{EtCO}_{2}\right)$ measurement, invasive blood pressure monitoring was also applied to all patients using an intra-arterial catheter. Airway pressures, ventilation parameters, inspired oxygen concentration $\left(\mathrm{FiO}_{2}\right)$, expired end-tidal carbon dioxide concentration $\left(\mathrm{EtCO}_{2}\right)$, and end-tidal sevoflurane concentration were monitored as well. Systolic arterial pressure (SAP), diastolic arterial pressure (DAP), mean arterial pressure (MAP), heart rate (HR), and respiratory rate (RR) were measured every 15 minutes in the operating room and in the postoperative intensive care unit.

\section{Anesthesia and surgical management}

All patients received intramuscular midazolam at a dose of $0.03 \mathrm{mg} / \mathrm{kg}$ (Dormicum, Deva Pharmaceutical, Turkey) 30 minutes before the operation. Moreover, each patient received general anesthesia, including anesthetic induction and maintenance. In our work, in addition to general anesthesia, the patients received epidural or intercostal catheters for postoperative pain management only; these catheters were not used for analgesia during surgery. Epidural or intercostal catheters were used postoperatively for pain management.

After preoxygenation, the induction of anesthesia was conducted using 5-7 mg/kg of thiopental (Pental, IE Ulugay Pharmaceutical Industry, Turkey), 2-5 $\mu \mathrm{g} / \mathrm{kg}$ of fentanyl (fentanyl Janssen, Janssen Pharmaceutica, Belgium), and 0.6 $\mathrm{mg} / \mathrm{kg}$ of a nondepolarizing neuromuscular blocking agent - rocuronium bromide (Esmeron, Organon Pharmaceuticals, USA). A double-lumen endobronchial tube (Broncho-cath; Mallinckrodt, Dublin, Ireland) intubation was performed. Anesthesia was maintained with end-tidal concentration of 0.5 to $2 \%$ sevoflurane (Sevorane, Abbott Pharmaceutical, USA). The administration of the nondepolarizing neuromuscular blocking agent was repeated as necessary. In both groups, intravenous fentanyl was given every hour at a dose of 1 to $2 \mu \mathrm{g} / \mathrm{kg}$. In all patients, the trachea was extubated at the end of the surgery. The depth of anesthesia was monitored using hemodynamic parameters (including heart rate), respiratory rate, and the presence of spontaneous breathing during end-tidal carbon dioxide $\left(\mathrm{EtCO}_{2}\right)$ measurement. In the event of tachycardia (an increase in heart rate above 100 beats per minute) or an increase in blood pressure of more than $20 \%$ in comparison to baseline, the anesthesia was supported with appropriate doses of fentanyl and sevoflurane, an inhalational anesthetic agent. After the insertion of catheters, hypotension (decrease of MAP below $20 \%$ of baseline MAP) was treated with an infusion of a bolus of isotonic fluid solution and intravenous ephedrine (Ephedrine, Osel Pharmaceutical, Turkey) at a bolus dose of $10 \mathrm{mg}$. Bradycardia (heart rate $<50$ beats/min) was treated with intravenous atropine (Atropin sulfate, Biofarma Pharmaceutical, Turkey) at a bolus dose of $0.5 \mathrm{mg}$. Vomiting was treated with $8 \mathrm{mg}$ of intravenous dexamethasone (Dexoject, Mefar Pharmaceutical, Turkey), while nausea was treated with 4 mg of intravenous ondansetron (Zofran $8 \mathrm{mg}$, GlaxoSmithKline Pharmaceutical, Turkey). In both patient groups, $50 \mathrm{mg}$ of intravenous diclofenac (Dikloron, Deva Pharmaceutical, Turkey) was administered every 12 hours.

\section{Endpoints}

The primary endpoint was pain at rest and on coughing. Pain intensity was measured at rest (VAS-R) and after coughing (VAS-C) using a VAS in which $0 \mathrm{~cm}$ indicates no pain and $10 \mathrm{~cm}$ indicates the worst pain possible. The pain was assessed by a blinded observer at baseline (immediately after the operation, as soon as the patient was able to respond to verbal comments to explain the intensity of pain) as well as 1, 6, and 24 hours after the surgery. Nausea/vomiting was evaluated as $0=$ absent, $1=$ mild nausea, and 2 = severe nausea and/or vomiting. A VAS-R score of 4 $\mathrm{cm}$ or less indicated an acceptable level of pain. If the VAS$R$ score was more than $4 \mathrm{~cm}$, the patients received an intravenous $2 \mathrm{mg}$ dose of morphine (Morphine HCL, Galen Pharmaceutical, Turkey) every 10 minutes up to the maxi- 
mum dose of $10 \mathrm{mg}$ per hour. All changes related to pain relief were made by pain service physicians, who were not blinded to the type of analgesia received by each patient. The secondary end point was total morphine consumption and morphine-related side effects (nausea and vomiting, urinary retention, pruritus, and sedation). 24-hour morphine consumption, complications, and adverse effects were recorded as well [15].

\section{Statistical analysis}

All analyses were performed using the SPSS Statistical Package 15.0 (SPSS Inc., California, USA). For sample size analysis, the PASS 11 software package (NCSS Inc., Utah, USA) was used. The sample size was determined in a previous study by Kanazi et al. [15] as depending on the measurement of VAS-R. For a difference of $2 \mathrm{~cm}$ in the VAS-R score between two groups and a standard deviation of $2 \mathrm{~cm}$, it was calculated that 21 patients need to be included in each group in order to achieve a confidence interval of $95 \%$ and statistical power of $80 \%$. The data are presented as mean and standard deviation (SD) or as frequencies and percentages. Differences were assessed using a chi square test or Fisher's exact test for categorical variables. Mann Whitney U-test was used for continuous or non-parametric data. After testing for normal distribution, the data were compared using a two-way analysis of variance (ANOVA) for repeated measurements. $P$ values $<0.05$ were considered statistically significant.

\section{Results}

The patients underwent posterolateral thoracotomy for the following procedures: in group $1-16$ patients (53.3\%) had lobectomy, 7 patients (23.3\%) had segmentectomy, 3 patients (10\%) had pneumonectomy and 4 patients (13.3\%) had mediastinal mass or cyst resection; in group $2-20$ patients (67\%) underwent lobectomy, 6 (20\%) patients had segmentectomy, and 4 (13.3\%) patients underwent pneumonectomy.

There were 45 men and 15 women. The median age was 56 years, and the median weight was $74.5 \mathrm{~kg}$. There were no statistically significant differences between the two groups in terms of age, sex, or weight $(p>0.05)$ (Table I).

The failure rate of the pain management method due to disconnection or dislocation of the catheter was as follows: in group $1-25 / 30,83.3 \%$ and in group $2-28 / 30,93.3 \%$ $(p=0.228)$.

In group 1, the $\mathrm{FEV}_{1}$ and FVC values $(79.5 \pm 15.82$ and $81.43 \pm 17.19$, respectively) showed no significant difference in comparison to the values from group 2 (83.77 \pm 14.09 and $86.53 \pm 15.57$, respectively) ( $p>0.05)$.

The comparison of preoperative and postoperative (after 1,6 , and 24 hours) $\mathrm{PaO}_{2}, \mathrm{PCO}_{2}$, and $\mathrm{SaO}_{2}$ values of both groups showed no difference $(p>0.05)$.

Tab. I. Baseline clinical characteristics of the study population

\begin{tabular}{|c|c|c|c|c|c|}
\hline \multirow{2}{*}{ Parameter } & \multicolumn{2}{|c|}{ Group $1(n=30)$} & \multicolumn{2}{|c|}{ Group $2(n=30)$} & \multirow{2}{*}{$P^{*}$} \\
\hline & Median & Range (min-max) & Median & Range (min-max) & \\
\hline Age (years) & 55.5 & $34-86$ & 57.5 & $19-80$ & 0.12 \\
\hline Sex $\left(n^{*}\right.$, female/male $)$ & $6 / 24$ & & $9 / 21$ & & 0.371 \\
\hline Weight (kg) & 76.5 & $50-110$ & 68 & $47-95$ & 0.2 \\
\hline Height $(\mathrm{cm})$ & 163 & $150-182$ & 167 & $150-186$ & 0.116 \\
\hline Body mass index & 25.0 & 17.3-34 & 23.5 & $17.7-37.1$ & 0.742 \\
\hline ASA classification $\left(n^{*}, \mathrm{I} / \mathrm{II} / \mathrm{III}\right)$ & $22 / 3 / 5$ & & $19 / 4 / 4$ & & 0.706 \\
\hline $\begin{array}{l}\text { Preoperative disease; } n(\%) \\
\text { Hypertension } \\
\text { Diabetes mellitus } \\
\text { Coronary artery disease } \\
\text { Chronic obstructive pulmonary disease }\end{array}$ & $\begin{array}{l}4(12) \\
1(3) \\
2(6) \\
3(10)\end{array}$ & & $\begin{array}{l}7(23) \\
4(16) \\
1(3) \\
3(10)\end{array}$ & & $\begin{array}{l}0.348 \\
0.161 \\
0.554 \\
1\end{array}$ \\
\hline $\begin{array}{l}\text { Histologic type of cancer; } n(\%) \\
\text { Squamous cell carcinoma } \\
\text { Adenocarcinoma } \\
\text { Undifferentiated large cell cancer } \\
\text { Adenosquamous carcinoma }\end{array}$ & $\begin{array}{l}20(67) \\
9(30) \\
1(3) \\
0(0)\end{array}$ & & $\begin{array}{l}14(47) \\
10(33) \\
3(10) \\
3(10)\end{array}$ & & $\begin{array}{l}0.118 \\
0.781 \\
0.301 \\
0.076\end{array}$ \\
\hline $\begin{array}{l}\text { Complications; } n \text { (\%) } \\
\text { Hypotension } \\
\text { Vomiting and nausea } \\
\text { Bradycardia } \\
\text { Respiratory complications } \\
\text { Pruritus }\end{array}$ & $\begin{array}{l}5(17) \\
2(7) \\
3(10) \\
\text { none } \\
\text { none }\end{array}$ & & $\begin{array}{l}\text { None } \\
8(27) \\
\text { none } \\
\text { none } \\
\text { none }\end{array}$ & & $\begin{array}{c}0.02^{*} \\
0.038^{\star} \\
0.076\end{array}$ \\
\hline Duration of surgery (min) & $210 \pm 58.04$ & $130-330$ & $189 \pm 53$ & $120-300$ & 0.149 \\
\hline Total morphine consumption (mg) & $13.53 \pm 7.46$ & $0-25$ & $18.67 \pm 10.4$ & $0-33$ & $0.032^{\star}$ \\
\hline Hospital stay (days) & 12 & $10-16$ & 13 & $10-18$ & 0.056 \\
\hline Mortality & none & & none & & \\
\hline
\end{tabular}


Tab. II. Comparison of postoperative visual analog scale scores at rest (VAS-R) 0, 1, 6, and 24 hours postoperatively

\begin{tabular}{lccccc} 
Time (hours) & Group 1 $(n=30)$ & Group 2 $(n=30)$ & $\begin{array}{c}\text { Group 1 vs. } \\
\text { Group 2 }\left(P^{*}\right)\end{array}$ & $\begin{array}{c}\text { Group comparison } \\
\text { Group 1 }\left(P^{* *}\right)\end{array}$ & $\begin{array}{c}\text { Group comparison } \\
\text { Group 2 }\left(P^{* *}\right)\end{array}$ \\
\hline Baseline & $5.2 \pm 2.2$ & $5.7 \pm 1.9$ & 0.433 & $\Delta$ & $\Delta$ \\
\hline 1 & $3.1 \pm 2.3$ & $4.4 \pm 1.6$ & $0.017^{*}$ & $<0.0001^{* *}$ & $<0.0001^{\star *}$ \\
\hline 6 & $1.8 \pm 2.3$ & $3.5 \pm 1.8$ & $0.001^{*}$ & $<0.0001^{* *}$ & $<0.0001^{\star *}$ \\
\hline 24 & $0.8 \pm 1.6$ & $1.9 \pm 2.1$ & $0.023^{*}$ & $<0.0001^{* *}$ & $<0.0001^{\star *}$ \\
\hline
\end{tabular}

$P^{\star}<0.05$ - statistically significant; values are mean \pm standard deviation; comparison between groups, ${ }^{\star *}$ comparison to baseline value in group $1, p=0.0001$; comparison to baseline value in group 2, $p=0.0001$

Tab. III. Comparison of postoperative visual analog scale scores after coughing (VAS-C) 0, 1, 6, and 24 hours postoperatively

\begin{tabular}{lccccc} 
Time (hours) & Group 1 $(n=30)$ & Group 2 $(n=30)$ & $\begin{array}{c}\text { Group 1 vs. } \\
\text { Group 2 }\left(P^{*}\right)\end{array}$ & $\begin{array}{c}\text { Group comparison } \\
\text { Group 1 }\left(P^{* *}\right)\end{array}$ & $\begin{array}{c}\text { Group comparison } \\
\text { Group 2 }\left(P^{* *}\right)\end{array}$ \\
\hline Basal & $7.7 \pm 0.9$ & $7.5 \pm 1.4$ & 0.969 & $\Delta$ & $\Delta$ \\
\hline 1 & $4.6 \pm 0.9$ & $5.5 \pm 1.2$ & $0.006^{*}$ & $<0.001^{* *}$ & $<0.001^{* *}$ \\
\hline 6 & $2.7 \pm 0.8$ & $3.7 \pm 1.5$ & $0.002^{*}$ & $<0.001^{* *}$ & $<0.001^{* *}$ \\
\hline 24 & $2.4 \pm 0.8$ & $3.6 \pm 1.8$ & $0.032^{*}$ & $<0.001^{* *}$ & $<0.001^{* *}$ \\
\hline
\end{tabular}

${ }^{*} P<0.05$ : statistically significant; values are mean \pm standard deviation; comparison between groups, ${ }^{* *}$ comparison to baseline value in group $1, p=0.0001$; comparison to baseline value in group $2, p=0.0001$

The VAS-R pain scores were similar at hour 0 (baseline); however, in group 1, the $1^{\text {st }}$ hour ( $3.1 \pm 2.3$ vs. $4.4 \pm 1.6$; $p=0.017), 6^{\text {th }}$ hour $(1.8 \pm 2.3$ vs. $3.5 \pm 1.8 ; p=0.001)$, and $24^{\text {th }}$ hour $(0.8 \pm 1.6$ vs. $1.9 \pm 2.1 ; p=0.023)$ VAS scores were significantly lower than in group 2 (Table II).

The VAS-C pain scores were similar at hour 0 (baseline); however, in group 1 , the $1^{\text {st }}$ hour ( $4.6 \pm 0.9$ vs. $5.5 \pm 1.2$; $p=0.006), 6^{\text {th }}$ hour $(2.7 \pm 0.8$ vs. $3.7 \pm 1.5 ; p=0.002)$, and $24^{\text {th }}$ hour $(2.4 \pm 0.8$ vs. $3.6 \pm 1.8 ; p=0.032)$ VAS scores were significantly lower than in group 2 (Table III).

The comparison of VAS pain scores revealed that the postoperative pain scores recorded after 1, 6, and 24 hours were significantly lower than the baseline values ( $p=0.001)$ (Table II and III).

The postoperative 24-hour use of additional analgesic morphine and its side effects were similar (Table I).

There was no statistically significant difference between the groups with regard to the use of single or double drains. All patients were extubated in the operating room and transferred to the intensive care unit on spontaneous ventilation. With regard to hemodynamic data, the measurements of SAP, DAP, MAP, HR, and RR values (taken every 15 minutes) were similar in the two groups ( $p>0.05)$.

24-hour morphine consumption in group 1 was statistically significantly lower than in group $2(13.53 \pm 7.46 \mathrm{mg}$ vs. $18.67 \pm 10.4 \mathrm{mg} ; p=0.032$ ) (Table I).

During the first 24 postoperative hours, 5 out of 30 patients (17\%) in group 1 experienced hypotension as compared with 0 patients in group $2(p=0.02)$. The incidence of nausea and vomiting in group 1 (2 patients, $7 \%$ ), was statistically significantly lower than in group 2 (8 patients, 27\%) $(p=0.038)$. Bradycardia was observed in 3 patients $(10 \%)$ in group 1 and 0 patients $(0 \%)$ in group $2(p=0.076)$ (Table I). Pruritus and respiratory depression were not found in any of the cases (Table I).
The complications encountered during the application of both catheters were recorded and compared. Catheter dislocation was observed in 3 patients $(3 / 30,10 \%)$ in the thoracic epidural group and 2 patients $(6.7 \%)$ in the intercostal block group. Hemorrhage, local anesthetic toxicity, and infection were not observed in either of the groups $(p>0.05)$.

\section{Discussion}

Few randomized controlled studies on the use of continuous administration of local anesthetics by different methods for post-thoracotomy pain relief have been conducted [8-13]. For this reason, we conducted a prospective, randomized, double-blinded clinical study, which demonstrated that both methods utilizing continuous infusion of $0.25 \%$ bupivacaine, through either a thoracic epidural or an intercostal catheter, provide adequate pain relief after thoracotomy within the first 24 postoperative hours. However, better control of analgesia, as demonstrated by the VAS (resting and coughing) pain scores, was achieved in the thoracic epidural group of patients. While 24-hour morphine consumption and opioid-related side effects were lower in the thoracic epidural group, we observed a higher incidence of hypotension constituting a serious side effect of the thoracic epidural pain relief method $[8,10]$. The intercostal block is technically easier to perform, and it is associated with lower incidence of hypotension [10, 15]; however, we observed that the use of opioids in the first 24 postoperative hours was higher in the intercostal group, causing opioid-related side effects, such as increased incidence of nausea/vomiting.

Debreceni et al. [11] randomly allocated 50 patients to receive $0.25 \%$ bupivacaine through a thoracic epidural $\left(T_{7-9}\right)$ or intercostal catheter at a bolus dose of $0.2 \mathrm{ml} / \mathrm{kg}$ 
infused at the rate of $5 \mathrm{ml} / \mathrm{h}$. They found that the patients in the thoracic epidural catheter group had a lower visual analog pain score 4,8 , and 12 hours after surgery, and they required less narcotics for breakthrough pain. No demonstrable difference in postoperative pulmonary function was observed between the two groups. It was reported that epidural analgesia is more effective in comparison to intercostal analgesia after thoracotomy surgery.

In another randomized, double-blinded, controlled study, in which all patients received thoracic epidural analgesia, additional infusion of $0.25 \%$ bupivacaine from an intercostal catheter at a dose of $4 \mathrm{ml} / \mathrm{h}$ for a total of 100 hours was compared to normal saline infusion [16]. This study revealed that infusing local anesthetics through an intercostal catheter did not make any significant change in the use of narcotics and did not exert any significant effect on the visual analog pain scores. What makes our study different is that we divided our patients into groups receiving either thoracic epidural or intercostal catheters. We observed no statistically significant difference in terms of morphine consumption between our patient groups in the first 24-hour postoperative period (group 1: $13.53 \pm 7.46$, group 2: $18.67 \pm 10.4, p=0.032$ ). The aforementioned study reported similar findings; however, total morphine consumption was significantly higher (normal saline group: $145.4 \pm 102.9$, bupivacaine group: $115.9 \pm 62.7, p=0.06$ ) The reason for the lower consumption of morphine in our patient population may be related to the use of diclofenac, an intravenous non-steroid anti-inflammatory agent, in the early postoperative period.

Perttunen et al. [17] randomly assigned patients to groups which received single intrathoracic blocks, epidural analgesia, or continuous paravertebral infusions of bupivacaine. They found no difference in terms of pain, morphine consumption, respiratory function, or adverse events. The administration of intrathoracic intercostal block at a total dose of $16 \mathrm{ml}$ of $0.5 \%$ bupivacaine at levels $T_{3}$ to $T_{7}$ resulted in pain relief during the first 24 hours; however, none of the investigated methods was considered best for pain relief, as they all required opioid consumption. In the study by Richardson et al. [9], 100 patients were randomly assigned to receive either thoracic epidural or thoracic paravertebral pain relief. This study demonstrated that a continuous infusion of $0.5 \%$ bupivacaine results in lower pain scores and lower morphine consumption in the first 24 postoperative hours in the paravertebral infusion group than in the epidural group (105 $\pm 20 \mathrm{mg}$ and $262 \pm 67 \mathrm{mg}$ ). However, it has also been noted that the concentration of bupivacaine was $0.25 \%$ in the epidural group and $0.5 \%$ in the paravertebral group; this difference in concentration may raise questions as to the validity of the conclusions. In our study, we used $0.25 \%$ bupivacaine in both groups in order to avoid data-related controversy and bias.

Other randomized trials reported by Kaiser et al. and Chan et al. had small sample sizes (13 or 20 patients in each group); therefore, it is difficult to rely on any conclusions drawn in these studies $[12,13]$. In turn, the recent review by
Detterbeck et al. [18] reported that continuous intercostal nerve blockade after thoracotomy with the use of an extrapleural catheter provides better pain relief and preservation of pulmonary function than systemic narcotics, and appears to be at least as effective as the epidural approach. Our findings in this prospective, randomized, double-blinded study do not support their suggestions. Our study was designed to determine whether intercostal infusion of bupivacaine was better than thoracic epidural analgesia for postoperative pain control. For this reason, the study design is different than the other mentioned studies [8, 10-13, 18]. In a series of patients who underwent lung resection, forty cases with thoracic epidural or intercostal block pain relief therapy using $0.25 \%$ bupivacaine were compared. In this study, non-steroidal analgesic consumption and pain scores in the epidural group were significantly lower than in the intercostal group [19]. In a study by Concha et al. [4] 16 patients (group 1) received a 5-segment intercostal block plus intravenous patient-controlled analgesia (PCA) morphine, whereas 15 patients (group 2) received PCA bupivacaine and fentanyl infusions through thoracic epidural catheters. An intercostal block with bupivacaine plus intravenous PCA morphine is a good alternative to thoracic epidural analgesia for post-thoracotomy pain management [4]. Although the efficacy of using a single dose of intercostal block has been questioned, the 5-segment blockade and routine addition of non-steroidal anti-inflammatory drugs during intercostal nerve block have been shown to improve the quality of analgesia and decrease the need for morphine [14, 16].

In summary, our study is in agreement with several previous studies $[9,16,19]$; however, other studies have found that intercostal block is a good alternative to thoracic epidural analgesia, as it is associated with similar pain scores and morphine consumption during the first 24 postoperative hours [4, 9, 12-14].

In recent studies, thoracic epidural analgesia with $0.125 \%$ bupivacaine is considered to be an alternative to $0.25 \%$ bupivacaine for thoracotomy pain management in the early postoperative period. The reason for this is that the combination of $0.125 \%$ bupivacaine together with fentanyl $(3 \mathrm{mg} / \mathrm{ml})$ or sufentanil $(1 \mathrm{mg} / \mathrm{ml})$ provides sufficient pain relief without significant side effects [20-22].

The reported adverse effects associated with thoracic epidural analgesia, as confirmed by a large series of patients, include: hypotension (3\%), nausea (22\%), and pruritus (22\%) (23). The most significant advantage of intercostal block is that it is technically easier to perform and is not associated with hypotension [4]. Our findings that intercostal block patients experience hypotension less often are in accordance with previous research. Several studies suggest that hypotension is not observed frequently and that the incidence of hypotension is similar in both the thoracic epidural and the intercostal block groups [23-25, 27]. We did not encounter any complications attributable to intercostal catheters. However, other authors have reported complications, including an infected rib that required subsequent resection $[13,26]$. In the study by Rawal et al. [27], the in- 
cidence of postoperative vomiting in the intercostal group (23\%) was significantly greater than in the thoracic epidural group (7\%). In our study, 24-hour morphine consumption was higher in the intercostal group than in the thoracic epidural group. In our opinion this constitutes the reason for the more frequent occurrence of adverse effects, such as nausea, vomiting, and pruritus, in the intercostal group.

Respiratory depression is a rare adverse effect of the use of thoracic epidural analgesia; however, the patients in this group need to be monitored in intensive care units [4, 23, 25]. Urinary retention is an adverse effect of the use of both epidural catheters and opioid analgesics, but we were not able to observe this clinical finding, as all our patients had urinary catheters during the first 24 postoperative hours [19, 23, 27].

The limitation of the study is that, although the sample size was sufficient to provide statistically significant differences in terms of VAS scores between the groups, it would be preferable to perform this kind of study on an even larger group of patients.

\section{Conclusions}

In summary, both pain relief methods have advantages and disadvantages for post-thoracotomy pain management. Continuous intercostal block should be considered in the case of patients for whom there exist contraindications for thoracic epidural analgesia, such as a history of back surgery, morbid obesity, malnutrition, and old age. With regard to post-thoracotomy pain, thoracic epidural analgesia provides better analgesic control; however, intercostal block may still be taken into consideration as it is technically easier to perform and is associated with lower incidence of hypotension.

\section{References}

1. Tiippana E, Nilsson E, Kalso E. Post-thoracotomy pain after thoracic epidural analgesia: a prospective follow-up study. Acta Anaesthesiol Scand 2003; 47: 433-438.

2. Rock P, Preston BR. Postoperative pulmonary complications. Curr Opin Anaesthesiol 2003; 16: 123-131.

3. Hashemzadeh S, Hashemzadeh K, Hosseinzadeh H, Maleki RA, Golzari S. Comparison thoracic epidural and intercostal block to improve ventilation parameters and reduce pain in patients with multiple rib fractures. J Cardiovasc Thorac Res 2011; 3: 87-91.

4. Concha M, Dagnino J, Cariaga M, Aguilera J, Aparicio R, Guerrero M. Analgesia after thoracotomy: epidural fentanyl/bupivacaine compared with intercostal nerve block plus intravenous morphine. J Cardiothorac Vasc Anesth 2004; 18: 322-326.

5. Yeğin A, Arslan A, Karslı B, Trakya A. The effects of intrapleural, intercostal and preemtive analgesia methods on postoperative analgesia during toracotomies. Klin J Med Sci 2003; 23: 141-144.

6. Kapıcıbaşı HO, Meydan B, Koşar A, Sönmez H, Kır A, Atasalihi A. In pain management after thoracotomies the effects of intercostal nevre blockade. Turkish Thoracic Journal 2008; 9: 57-59.

7. Faheem M, Sarwar N. Sliding of the skin over subcutaneous tissue is another important factor in epidural catheter migration. Can J Anaesth 2002; 49: 634.

8. Richardson J, Sabanathan S, Eng J, Mearns AJ, Rogers C, Evans CS, Bembridge J, Majid MR. Continous intercostal nerve block versus epidural morphine for postthoracotomy analgesia. Ann Thorac Surg 1993; 55: 377-380.
9. Richardson J, Sabanathan S, Jones J, Shah RD, Shemma S, Mearns AJ. A prospective, randomized comparison of preoperative and continuous balance epidural or paravertebral bupivacaine on postthoracotomy pain, pulmonary function and stress response. Br J Anaesth 1999; 83: 387-392.

10. Dauphin A, Lubanska-Hubert E, Young JE, Miller JD, Bennett WF, Fuller HD. Comparative study of continuous extrapleural intercostal nerve block and lumbar epidural morphine in post-thoracotomy pain. Can J Surg 1997; 40: 431-436.

11. Debreceni G, Molnár Z, Szélig L, Molnár TF. Continuous epidural or intercostal analgesia following thoracotomy: a prospective randomized double-blind clinical trial. Acta Anaesthesiol Scand 2003; 47: 1091-1095.

12. Kaiser AM, Zollinger A, De Lorenzi D, Largiadèr F, Weder W. Prospective, randomized comparison of extrapleural versus epidural analgesia for postthoracotomy pain. Ann Thorac Surg 1998; 66: 367-372.

13. Chan VWS, Chung F, Cheng DCH, Seyone C, Chung A, Kirby T. Analgesic and pulmonary effects of continuous intercostal nerve block following thoractomy. Can J Anaesth 1991; 38: 733-739.

14. Meierhenrich R, Hock D, Kühn S, Baltes E, Muehling B, Muche R, Georgieff M, Gorsewski G. Analgesia and pulmonary function after lung surgery: is a single intercostal nerve block plus patient-controlled intravenous morphine as effective as patient-controlled epidural anaesthesia? A randomized noninferiority clinical trial. Br J Anaesth 2011; 106: 580-589.

15. Kanazi GH, Ayoub CM, Aouad M, Abdallah F, Sfeir PM, Adham A-BF, et al. Subpleural block is less effective than thoracic epidural analgesia for postthoracotomy pain: a randomised controlled study. Eur J Anaesthesiol 2012; 29: $186-191$.

16. Allen MS, Halgren L, Nichols FC 3rd, Cassivi SD, Harmsen WS, Wigle DA, Shen KR, Deschamps C. A randomized controlled trial of bupivacaine through intracostal catheters for pain management after thoracotomy. Ann Thorac Surg 2009; 88: 903-910.

17. Perttunen K, Nilsson E, Heinonen J, Hirvisalo EL, Salo JA, Kalso E. Extradural, paravertebral and intercostal nerve blocks for post-thoracotomy pain. $\mathrm{Br}$ J Anaesth 1995; 75: 541-7.

18. Detterbeck FC. Efficacy of methods of intercostal nerve blockade for pain relief after thoracotomy. Ann Thorac Surg 2005; 80: 1550-1559.

19. Sanjay OP, Prashanth P, Tauro DI. Intercostal nerve blockade versus thoracic epidural analgesia for post thoracotomy pain relief. Ind J Thorac Cardiovasc Surg 2003; 19: 141-144.

20. Mendola C, Ferrante D, Oldani E, Cammarota G, Cecci G, Vaschetto R, Della Corte $\mathrm{F}$. Thoracic epidural analgesia in post-thoracotomy patients: comparison of three different concentrations of levobupivacaine and sufentanil. $\mathrm{Br}$ J Anaesth 2009; 102: 418-23.

21. De Cosmo G, Mascia A, Clemente A, Congedo E, Aceto P. Use of levobupivacaine for the treatment of postoperative pain after thoracotomies. Minerva Anestesiol 2005; 71: 347-351.

22. Tekelioglu UY, Gurses EL, Serin S, Sungurtekin H. Combinations of fentanyl and levobupivacaine for post-thoracotomy pain. Acta Anaesthesiol Taiwan 2012; 50: 131-133.

23. De Leon-Casasola OA, Parker B, Lema MJ, Harrison P, Massey J. Postoperative epidural bupivacaine-morphine therapy. Experince with 4,227 surgical cancer patients. Anesthesiology 1994; 81: 368-375.

24. Wurnig PN, Lackner H, Teiner C, Hollaus PH, Pospisil M, Fohsl-Grande B, Osarowsky M, Pridun NS. Is intercostal block for pain management in thoracic surgery more successful than epidural anaesthesia? Eur J Cardiothorac Surg 2002; 21: 1115-1119.

25. de Almeida MC, de Figueiredo Locks G, Gomes HP, Brunharo GM, Kauling AL. Postoperative analgesia: comparing continuous epidural catheter infusion of local anesthetic and opioid and continuous wound catheter infusion of local anesthetic. Rev Bras Anestesiol 2011; 61: 293-303.

26. Çelik B, Hamzaçebi H, Kefeli H. Postthoracotomy pain: intercostal nevre blockade with use of prilocaine, bupivacaine and ropivacaine. Akciger Arşivi 2007; 8: 122-126.

27. Rawal N, Sjöstrand UH, Dahlström B, Nydahl PA, Ostelius J. Epidural morphine for postoperative pain relief: a comparative study with intramuscular narcotic and intercostal nerve block. Anesth Analg 1982; 61: 93-95. 